\title{
Nitrogen Oxides and Particulate Matter from Marine Diesel Oil (MDO), Emulsified MDO, and Dimethyl Ether Fuels in Auxiliary Marine Engines
}

\author{
Jinkyu Park ${ }^{1}$, Iksoo Choi ${ }^{2}$, Jungmo Oh ${ }^{1}\left[\right.$ and Changhee Lee ${ }^{3, *(1)}$ \\ 1 Division of Marine Engineering, Mokpo National Maritime University, Mokpo 58628, Korea; \\ pjk2019@mmu.ac.kr (J.P.); jmoh@mmu.ac.kr (J.O.) \\ 2 STX Engine Ltd., Changwon-ci, Kyungsangnam-do 51574, Korea; nicsu@onestx.com \\ 3 Department of Mechanical and Shipbuilding Convergence Engineering, Pukyong National University, \\ Busan 48547, Korea \\ * Correspondence: leemech@pknu.ac.kr; Tel.: +82-51-629-7816
}

Received: 7 April 2020; Accepted: 28 April 2020; Published: 1 May 2020

\begin{abstract}
Exhaust gases from ships and automobiles have a significant impact on people and the environment. As a result, diesel engines used in land and marine vehicles are gradually being restricted, and low-carbon engines are under development. This study considers marine diesel oil (MDO) that is used in ships to meet the emission regulations required by the International Maritime Organization. This investigation explores the method and application technology for the reduction of nitrogen oxides $\left(\mathrm{NO}_{\mathrm{x}}\right)$ and particulate matter using emulsified fuel and mass-produced dimethyl ether (DME) fuel, which are analyzed. When comparing emulsified fuel and DME fuel to MDO, which is a ship oil, $\mathrm{NO}_{x}$ are reduced by $20-45 \%$ and the particulate matter is reduced by $60-97 \%$. When emulsified fuel containing moisture is used, the combustion chamber temperature is lowered due to the optimal expansion by moisture contained in the fuel. The particulate matter is also reduced. When DME fuel is used, it reduces the particulate matter by more than $97 \%$ in comparison with the existing MDO fuel and the emulsified fuel. The conditions are believed to be suitable for combustion and they can be satisfied by supplying oxygen during post-combustion.
\end{abstract}

Keywords: marine diesel oil; emulsified marine diesel oil; nitrogen oxides emission; particulate matter; dimethyl ether fuels

\section{Introduction}

Exhaust gases from ships and automobiles have a significant impact on people and the environment. As a result, diesel engines used in land and marine vehicles are gradually being restricted and low-carbon engines are currently being developed. In accordance with the regulations of the International Maritime Organization (IMO) [1], the emission control area is determined in accordance with international conventions for the prevention of pollution from ships. Emissions must be managed in emission control areas. Due to the limitations of exhaust gases, especially nitrogen oxides $\left(\mathrm{NO}_{\mathrm{x}}\right)$ emissions, internal combustion engines are being applied to reduce $\mathrm{NO}_{x}$ and particulate matter (PM) in exhaust gases using the 'optimal emulsifying fuel composition'. Therefore, it should be noted that estimation and forecasting of diesel engine emissions is very important in this context [2]. Moreover, predicting emissions from diesel engines in real time is not an easy task. With the development of powerful, accurate, and fast predictive algorithms, diesel engine exhaust can be controlled in real time.

Meanwhile, studies on $\mathrm{NO}_{x}$ reduction using emulsified fuels have been actively conducted. Lim et al. [3,4] showed a deterioration in the fuel efficiency at low loads when the test diesel engine was operated by dispersing water in light oil with a mixer using ultrasonic and shear force without using 
additives, but at high loads. Favourable operating conditions, stabilization of fuel economy, and a high $\mathrm{NO}_{\mathrm{x}}$ reduction rate were confirmed. However, by mixing water, light oil, and additives, and applying an emulsified fuel in oil-in-water, the fuel efficiency is improved by reducing $\mathrm{NO}_{\mathrm{x}}$, which dramatically reduces the particulate matter. For this reason, by mixing water particles in light oil, the combustion chamber temperature decreases due to micro-explosions caused by the phase change of water. In addition, the post combustion combusts rapidly due to atomization, thereby significantly reducing the particulate matter [5-11]. Specifically, heavy fuel oil (HFO), which is used as a ship fuel, has high density characteristics relative to on-shore fuels; hence, it is easy to emulsify, and has the feature of separating oil and water; thus, it is highly practical. Kawasaki Heavy Industries applied emulsion fuel to bulk carriers of 58,000 tons (MAN B\&W 6S50MC-C, $8630 \mathrm{~kW} / 116 \mathrm{rpm}$ ) and succeeded in continuous operations [12] for $2740 \mathrm{~h}$. This suggests the possibility of using emulsion fuel for vessels. This emulsion fuel was proven to be effective in reducing the particulate matter, as well as $\mathrm{NO}_{\mathrm{x}}$. Murayama et al. [6] confirmed the reduction effect of $48 \%$ using emulsion fuel. However, since the method of using the emulsion fuel has a reduction rate of $\mathrm{NO}_{\mathrm{x}}$ that does not meet the IMO regulation value, the disadvantage is that it is difficult to achieve the target value with this method alone.

For a long time, the search has been on to find a fuel for compression engines that is environmentally friendly and can be easily stored and transported. Dimethyl ether (DME, $\mathrm{CH}_{3}-\mathrm{O}-\mathrm{CH}_{3}$ ) [11] is an alternative fuel for diesel engines that has a low auto ignition temperature. It also has good evaporative performance when sprayed into the combustion chamber, and it has a higher cetane number $(>55)$ than diesel fuel. In particular, DME is an oxygen-containing fuel that consists of $34.8 \mathrm{wt} . \%$ oxygen. As there is no direct coupling between carbon and carbon in the fuel characteristics, almost no particulate matter is emitted in the diesel engine [12-19]. Due to these advantages, it is possible to apply a large amount of exhaust gas recirculation (EGR) without much difficulty to the engine. This can greatly reduce $\mathrm{NO}_{\mathrm{x}}$ and has many excellent characteristics as an alternative fuel for diesel engines [19-24].

Industrially mass-produced DME is a very promising alternative fuel for diesel engines [25-27]. DME has a simple molecular structure, $\mathrm{C}-\mathrm{O}-\mathrm{C}$ without a $\mathrm{C}-\mathrm{C}$ bond. DME also has a very high cetane number ( $>55)$, high oxygen content ( 34.8 mass $\%)$, and better atomization, combustion, and fuel economy than diesel $[28,29]$. DME is also known as a potentially very clean fuel that does not have much smoke, and can be burned without particulate matter emissions. In addition, a high EGR allows $\mathrm{NO}_{\mathrm{x}}$ emissions to be controlled to meet increasingly stringent regulatory standards [30] for application to diesel engines. These properties include the bulk modulus, low calorific values, and viscosity. The bulk modulus and viscosity values of DMEare much lower than diesel's bulk modulus and viscosity values. This leads to higher pressures, intense pressure fluctuations, and steam leaks in fuel delivery systems (e.g., high-pressure pumps, common rails, injectors). In order to solve this problem, it is not possible to use a fuel supply device for general diesel; thus, a fuel supply system dedicated to DME must be applied. [31,32]. A realistic alternative is biodiesel [33-36], which is an alternative oxygenated fuel for diesel engines. Biodiesel is gaining momentum due to its sustainability, good exhaust quality, and biodegradability [37-40]. In DME engines, a good lubricity and a high calorific biodiesel complement the properties of DME and eliminate the use of lubricating additives by mixing biodiesel.

Developing new combustion techniques to improve performance and reduce the emissions is a difficult and expensive option. Some notable works on homogeneous charge compression ignition as a potential combustion technology for DME combustion have shown promising results with a simultaneous reduction of $\mathrm{NO}_{\mathrm{x}}$ and particulate matter emissions [29,41-43]. Other possible methods for achieving complete combustion and less emissions include a controlled fuel injection strategy [44-51], fuel injector configuration, injection pressures, and employing combustion after treatment processes such as EGR, oxidation catalysts, and particle filters [52,53]. In this review paper, the effect of injection strategies, fuel additives, and exhaust gas after treatment techniques on emissions are thoroughly examined in order to suggest the optimum methods for reducing emissions. In the end, a summary is drawn to show the direction in which research on DME as an alternative fuel should be focused to achieve the goals of reduced emission and better combustion. 
Finally, comparative values of $\mathrm{NO}_{\mathrm{x}}$ emissions from DME compression ignition engines and those from diesel fuel vary depending on the engine conditions and the fuel supply system. Some studies found that $\mathrm{NO}_{x}$ emissions are lower, while other studies have reported the opposite [54,55]. To lower $\mathrm{NO}_{\mathrm{x}}$ emissions, some researchers reported that DME combustion results in lower $\mathrm{NO}_{\mathrm{x}}$ emissions [56-58] than diesel combustion. The reasons for this include a lower heating value, the higher heat of vaporization, a shorter ignition delay, a reduced amount of fuel that is injected during the ignition delay period, and a decreased amount of fuel burned during the premixed burning phase. As a result, this can lead to a lower peak combustion temperature. In regard to higher $\mathrm{NO}_{\mathrm{x}}$ emissions, it is possible that a higher amount of $\mathrm{NO}_{x}$ can be produced from DME than from diesel fuel for an early injection start. This is because the duration of the peak temperature would be longer in the initial combustion period due to the shorter ignition delay of DME. When injection retardation is optimized for each fuel, $\mathrm{NO}_{\mathrm{x}}$ from DME is lower than that of diesel fuel [57].

In this study, the experimental data and numerical analysis results were compared and analyzed using the existing marine diesel engine's experimental data and AVL BOOST (www.avl.com/boost). The numerical analysis was conducted on the characteristics of $\mathrm{NO}_{\mathrm{x}}$ and particulate matter reduction in marine engines using emulsified fuel and DME fuel according to the content of fuel and water used in the marine engine. In general, a study was conducted on the exhaust characteristics of oil-in-water emulsion fuel through marine fuel, moisture, and additives. In addition, combustion and exhaust characteristics based on the excess air ratio according to the compression ratio change of the turbocharger were analyzed using emulsified fuel with a moisture content of $16 \%$. In addition, the characteristics of $\mathrm{NO}_{x}$ and particulate matter emission from DME fuel and emulsion fuel similar to diesel fuel were compared and analyzed. This study analyzed the combustion and exhaust characteristics based on the hole diameter and the injection timing of the nozzle of a general marine diesel engine. This research was focused on combustion and exhaust reduction based on the optimal hole diameter and the injection timing.

\section{Materials and Research Methods}

\subsection{Experimental Method}

Regarding the engine used in this study, a $600-\mathrm{kW}$-class generator engine was constructed, as shown in Figure 1. The experimental apparatus includes Encoder, which can measure the number of revolutions of the engine on the crankshaft, and a pressure sensor (model $6056 \mathrm{~A}$, Kistler, Winterthur, Switzerland) on cylinder 1 to measure the pressure in the combustion chamber, and measures the combustion pressure. In addition, to measure the flow rate of the incoming fuel, a flow meter, a load regulator, and a system capable of measuring $\mathrm{NO}_{\mathrm{x}}$ and particulate matter were installed at the outlet of the exhaust outlet. Tables 1-3 show the engine specifications, exhaust gas measurement devices, and experimental conditions used in this study, respectively. Table 4 shows the experimental conditions of the study. The key properties of emulsified marine diesel oil (MDO), DME, and marine diesel fuel are shown in Table $4[8,57,59]$. In addition to the advantages above, it has a low carbon-to-hydrogen ratio $(\mathrm{C}: \mathrm{H})$, with the chemical formula $\mathrm{CH}_{3}-\mathrm{O}-\mathrm{CH}_{3}$.

Table 1. Specifications for the test engine.

\begin{tabular}{|c|c|}
\hline Items/Descriptions & Specifications \\
\hline Engine type & $\begin{array}{l}\text { Four-stroke turbo-charged direct injection marine } \\
\text { generator engine }\end{array}$ \\
\hline Number of cylinders & 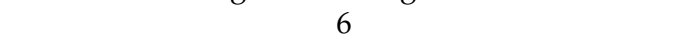 \\
\hline Compression ratio & 15.9 \\
\hline Bore $\times$ Stroke $(\mathrm{mm})$ & $165 \times 265$ \\
\hline Displacement (cc) & 20,000 \\
\hline Fuel injection system & Mechanical pumping system (Max. 1400 bar) \\
\hline Engine's maximum continuous rating (MCR) (kW/rpm) & $600 \mathrm{~kW} / 900 \mathrm{rpm}$ \\
\hline
\end{tabular}


Table 2. Exhaust gas instrument.

\begin{tabular}{cc}
\hline Items & Specification \\
\hline Dynamometer & Load controller (in a marine ship) \\
Exhaust gas Analyzer & cold-dry method and uses NDIR modules \\
Smoke meter & Diesel opacimeter (OP 130D) \\
\hline
\end{tabular}

Table 3. Numerical conditions.

\begin{tabular}{cc}
\hline \multirow{2}{*}{ Fuel } & Marine Diesel Oil \\
\cline { 2 - 2 } & Emulsified Marine Diesel Oil of $\mathbf{1 0} \% \mathbf{, ~ 1 3 \% , ~ a n d ~ 1 6 \% ~ M o i s t u r e ~ C o n c e n t r a t i o n s ~ [ 8 ] ~}$ \\
\cline { 2 - 2 } & DME Fuel \\
\hline Engine speed (rpm) & 900 \\
\hline Load $(\mathrm{kW})$ & $150,300,450,600$ \\
\hline
\end{tabular}

Table 4. Properties of MDO, emulsified MDO (EMDO), and DME fuel.

\begin{tabular}{|c|c|c|c|c|c|c|}
\hline Property (Unit/Condition) & Unit & $\begin{array}{l}\text { DME } \\
{[57,59]}\end{array}$ & $\underset{[8]}{\operatorname{EMDO} \_10 \%}$ & $\underset{[8]}{\text { EMDO_13\% }}$ & $\begin{array}{c}\text { EMDO_16\% } \\
{[8]}\end{array}$ & $\begin{array}{c}\text { Diesel Fuel } \\
{[57,59]}\end{array}$ \\
\hline Chemical structure & - & $\mathrm{CH}_{3}-\mathrm{O}-\mathrm{CH}_{3}$ & - & - & - & - \\
\hline Molar mass & $\mathrm{g} / \mathrm{mol}$ & 46 & - & - & - & 170 \\
\hline Carbon content & mass $\%$ & 52.2 & 79.1 & 77.6 & 76.1 & 86 \\
\hline Hydrogen content & mass $\%$ & 13 & 13.1 & 12.9 & 12.0 & 14 \\
\hline Oxygen content & mass $\%$ & 34.8 & 0 & 0 & 0 & 0 \\
\hline Carbon-to-hydrogen ratio & - & 0.337 & - & - & - & 0.516 \\
\hline Critical temperature & K & 400 & - & - & - & 708 \\
\hline Critical pressure & $\mathrm{MPa}$ & 5.37 & - & - & - & 3.00 \\
\hline Critical density & $\mathrm{kg} / \mathrm{m}^{3}$ & 259 & - & - & - & - \\
\hline Liquid density & $\mathrm{kg} / \mathrm{m}^{3}$ & 667 & 872 & 878 & 882 & 831 \\
\hline Relative gas density (air = 1) & - & 1.59 & - & - & - & - \\
\hline Cetane number & - & $>55$ & - & - & - & $40-50$ \\
\hline Auto-ignition temperature & K & 508 & - & - & - & 523 \\
\hline $\begin{array}{l}\text { Stoichiometric air/fuel mass } \\
\text { ratio }\end{array}$ & - & 9.0 & - & - & - & 14.6 \\
\hline Boiling point at $1 \mathrm{~atm}$ & K & 248.1 & - & - & - & $450-643$ \\
\hline Enthalpy of vaporization & $\mathrm{kJ} / \mathrm{kg}$ & 467.13 & - & - & - & 300 \\
\hline Lower heating value & $\mathrm{MJ} / \mathrm{kg}$ & 27.6 & 36.8 & 34.6 & 33.4 & 42.5 \\
\hline Gaseous specific heat capacity & $\mathrm{kJ} / \mathrm{kg} \mathrm{K}$ & 2.99 & - & - & - & 1.7 \\
\hline Ignition limits & $\begin{array}{l}\text { vol } \% \text { in } \\
\text { air }\end{array}$ & $3.4 / 18.6$ & - & - & - & $0.6 / 6.5$ \\
\hline Modulus of elasticity & $\mathrm{N} / \mathrm{m}^{2}$ & $6.37 \times 10^{8}$ & - & - & - & $14.86 \times 10^{8}$ \\
\hline Kinematic viscosity of liquid & $\mathrm{cSt}$ & $<0.1$ & - & - & - & 3 \\
\hline Surface tension (at $298 \mathrm{~K}$ ) & $\mathrm{N} / \mathrm{m}$ & 0.012 & - & - & - & 0.027 \\
\hline Vapor pressure (at $298 \mathrm{~K}$ ) & $\mathrm{kPa}$ & 530 & 10 & 10 & 10 & 10 \\
\hline Moisture & Vol\% & 0 & 11 & 13.5 & 16.1 & 0 \\
\hline
\end{tabular}

\subsection{Numerical Analysis Method}

The software adopted for the simulation was AVL BOOST@), version 2019.1(AVL List GmbH, Graz, Austria) which provides a graphical user interface (GUI) with icons representing the components of the internal combustion engine (ICE). For the engine in Figure 1, a simulation model was constructed 
using icons as shown in Figure 2a, and once all necessary data was collected, the model was built in AVL BOOST ${ }^{\mathrm{TM}}$ software [60] and turbocharger (TC1) model was controlled on the air flow rate of the turbocharger, as shown in Figure $2 \mathrm{~b}$. Figure $2 \mathrm{c}$ shows the combustion chamber pressure and heat generation rate characteristics for the experimental and numerical results (Figure 2a). First, the experimental results and numerical values using MDO show similar results. Through the test results and numerical analysis results, the combustion and heat generation rates according to water content were compared after verification. The numerical results in Figure $2 \mathrm{c}$ show that the maximum combustion pressure increases with increasing water content. Furthermore, based on the heat generation rate characteristics, the numerical results show that the combustion pressure decreases as the water content increases, and combustion is actively performed [61].

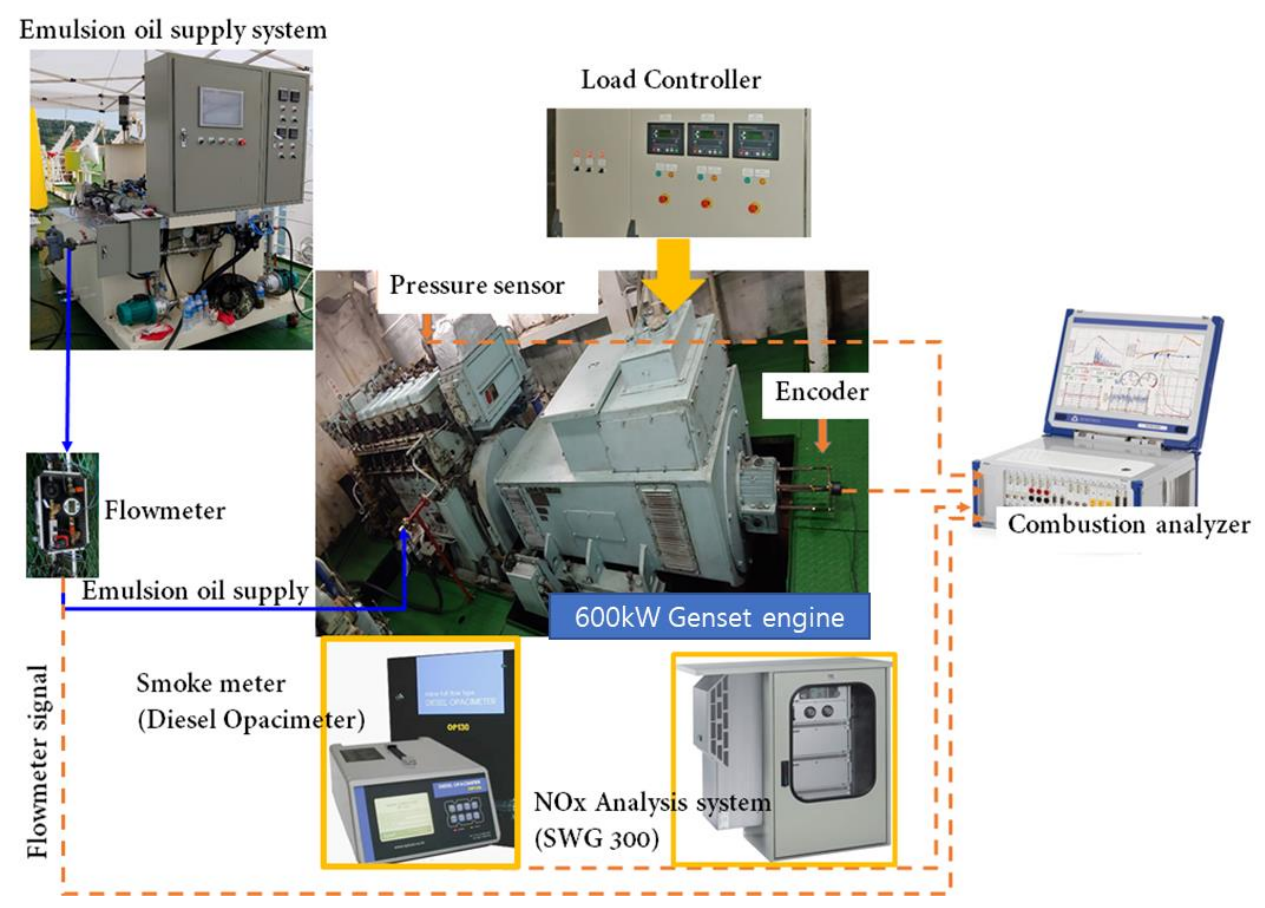

Figure 1. Schematic for a four-stroke marine engine, the data was from [61].

In the simulation model, initial and boundary conditions were established by modelling cylinders, turbochargers, valves or heat exchangers, and engine components. The modelled engine configuration considered reference cylinder $1(\mathrm{C} 1)$, the main engine characteristics for the spatial distribution of the cylinders, namely, the explosion sequence $\mathrm{C} 1-\mathrm{C} 2-\mathrm{C} 4-\mathrm{C} 6-\mathrm{C} 5-\mathrm{C} 3$ and the firing angle of each cylinder. The model's C1 (AVL BOOST ${ }^{\mathrm{TM}}$ ) is associated with Element 1 Engine 1 (E1) and defines the engine type, operating speed, moment of inertia, and brake average effective pressure (BMEP) used. The combustion method adopts an experimental mixed control combustion (MCC) AVL combustion model that predicts the amount of heat released (ROHR) and $\mathrm{NO}_{x}$ emissions based on the amount of fuel in the cylinder and turbulent kinetic energy from injection. 


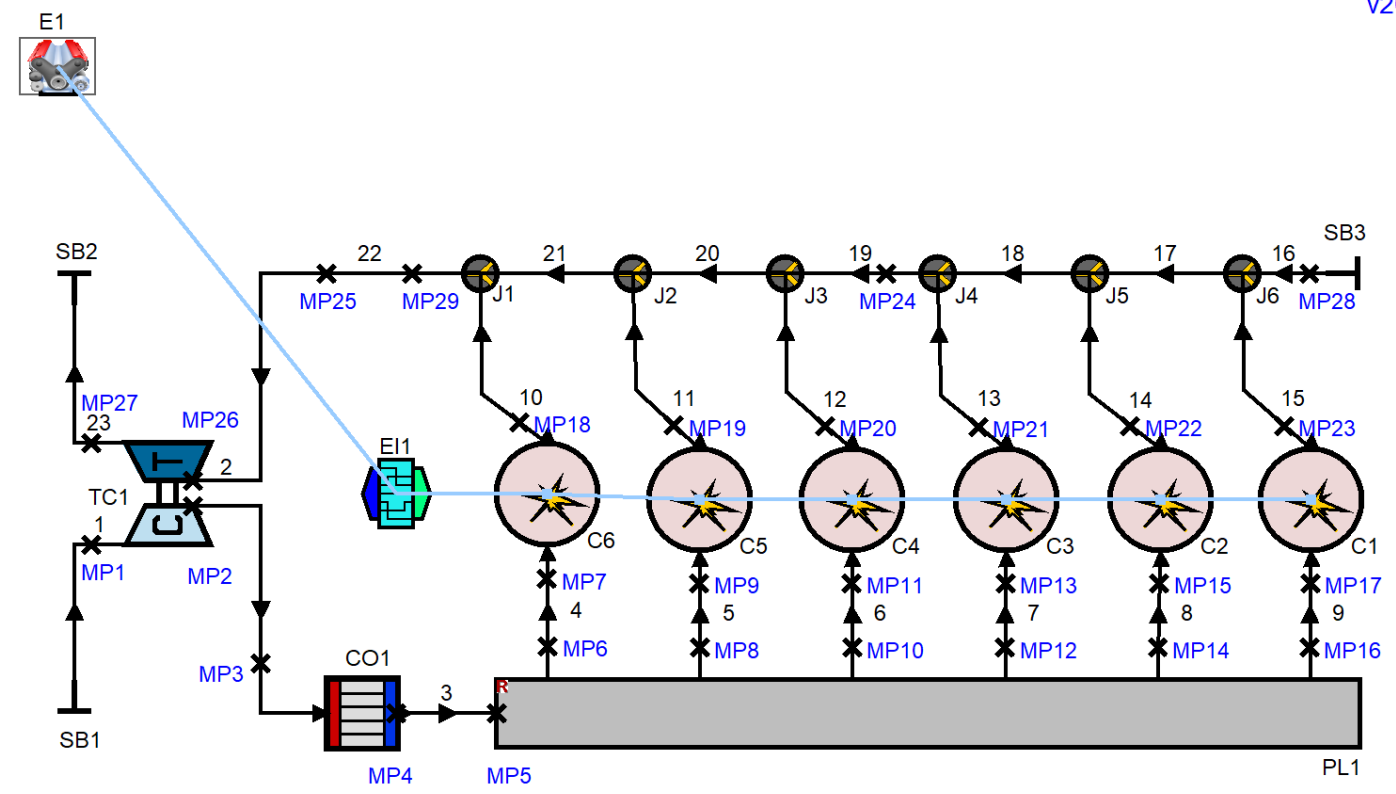

(a) AVL BOOST model

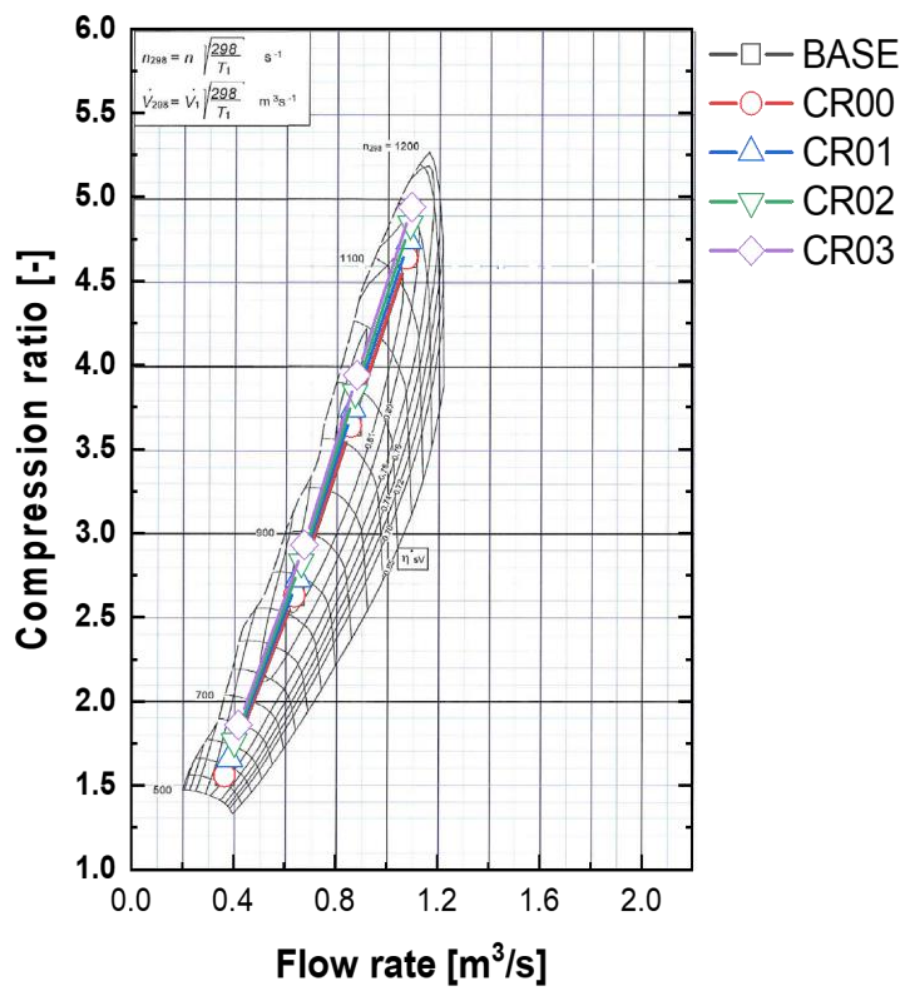

(b) Turbocharger experimental data in accordance with compression ratio

Figure 2. Cont. 


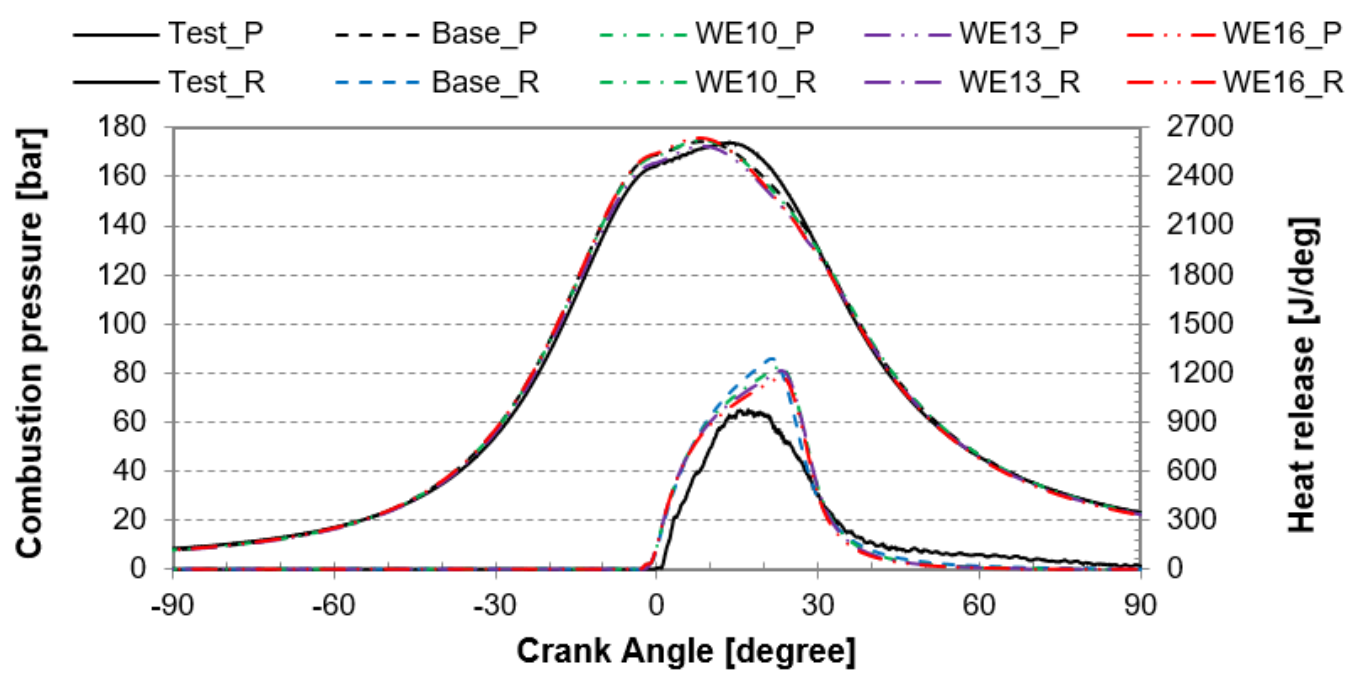

(c) Verification of numerical and experimental results with engine of Figure 1 [61]

Figure 2. AVL BOOST ${ }^{\mathrm{TM}}$ model and turbocharger data for a four-stroke marine diesel engine. (Test: Experimental data, Base: Numerical data, P: combustion pressure, R: heat release, WE10: water emulsion including $10 \%$ of moisture concentration).

\section{Results and Investigation}

\subsection{Combustion Characteristics in Accordance with MDO, EMDO, and DME Fuels}

Figure 3 displays the results of the combustion pressure characteristics of the marine engine according to the injection timing change using MDO, emulsified MDO (EMDO), and DME fuels. Compared with the combustion pressure of MDO, the pressure ratio of EMDO and the turbocharger containing 16\% water increases, and the combustion pressure increases when DME fuel is used. As the moisture content of the water increases, it is believed that the moisture contained in the EMDO fuel increases the combustion pressure due to volume expansion because of the water's phase change. For the case of DME fuel, the injection timing shows similar combustion characteristics for 2.0 CA BTDC; however, the combustion pressure tends to increase significantly as the injection timing advances.

Figure 4 illustrates the ship engine's rate of heat release according to the injection timing change using MDO, EMDO, and DME fuels. After considering the heat generation rate results while using MDO fuel, there is a rapid heat generation rate and a longer post-combustion property compared with EMDO and DME fuels, which causes particulate matter generation. In addition, $\mathrm{NO}_{\mathrm{x}}$ generation and post-combustion increase as the combustion chamber temperature increases due to rapid combustion. When EMDO contains moisture, it somewhat slows the combustion characteristics and shortens the post-combustion characteristics compared with the basic MDO. For this reason, $\mathrm{NO}_{\mathrm{x}}$ and particulate matter are expected to decrease. In addition, DME fuel contains 30\% or more oxygen. This shows the heat generation rate at the same injection time in comparison with the existing MDO. In addition, it shows a very gentle heat generation rate and the post combustion is rapidly shortened. Therefore, it is believed that $\mathrm{NO}_{x}$ and particulate matter will be reduced very rapidly. Based on the characteristics of combustion pressure and the heat generation rate using various fuels, it is possible to analyze the emissions of $\mathrm{NO}_{\mathrm{x}}$ and particulate matter. 


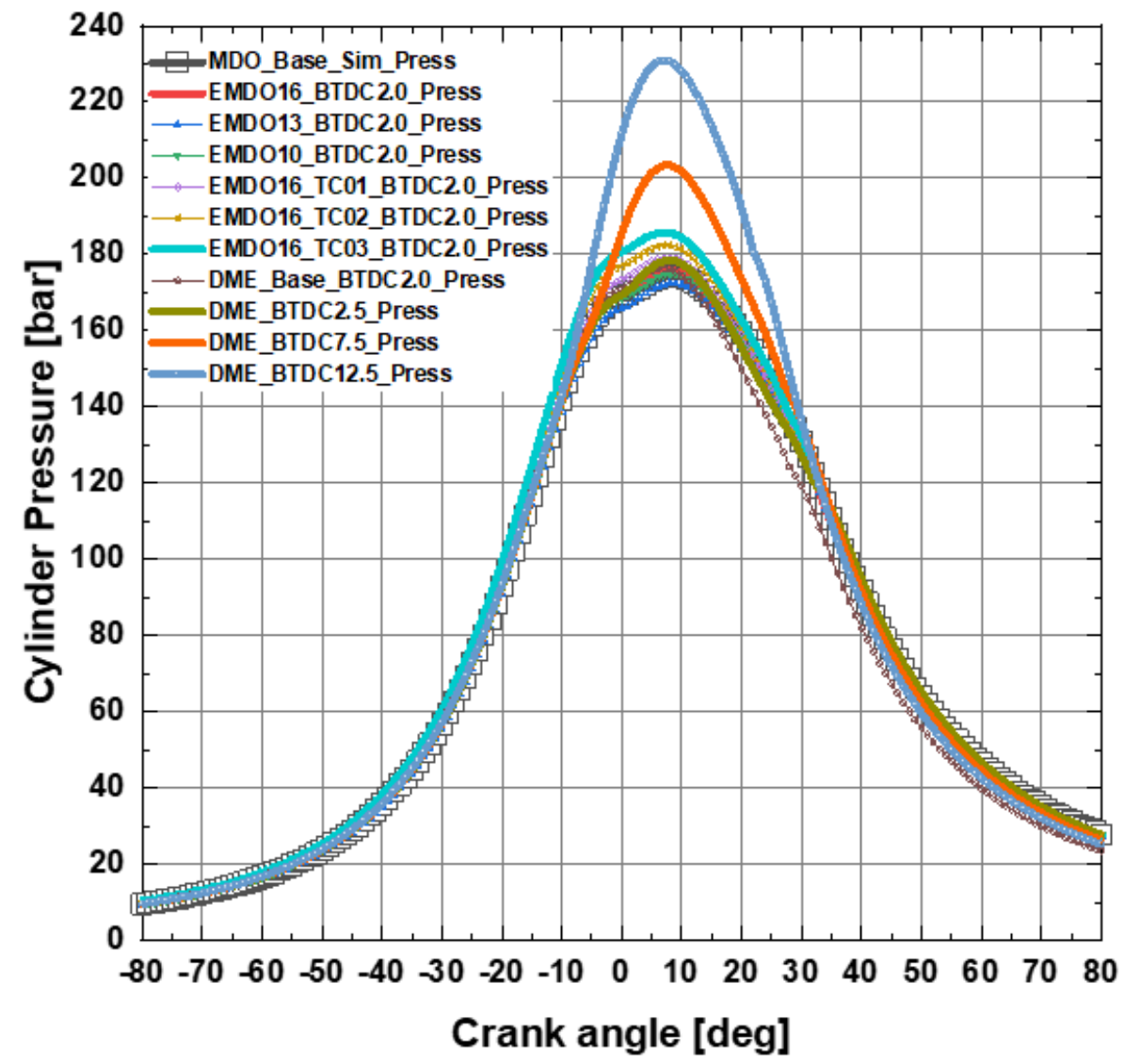

(a) Whole database graph

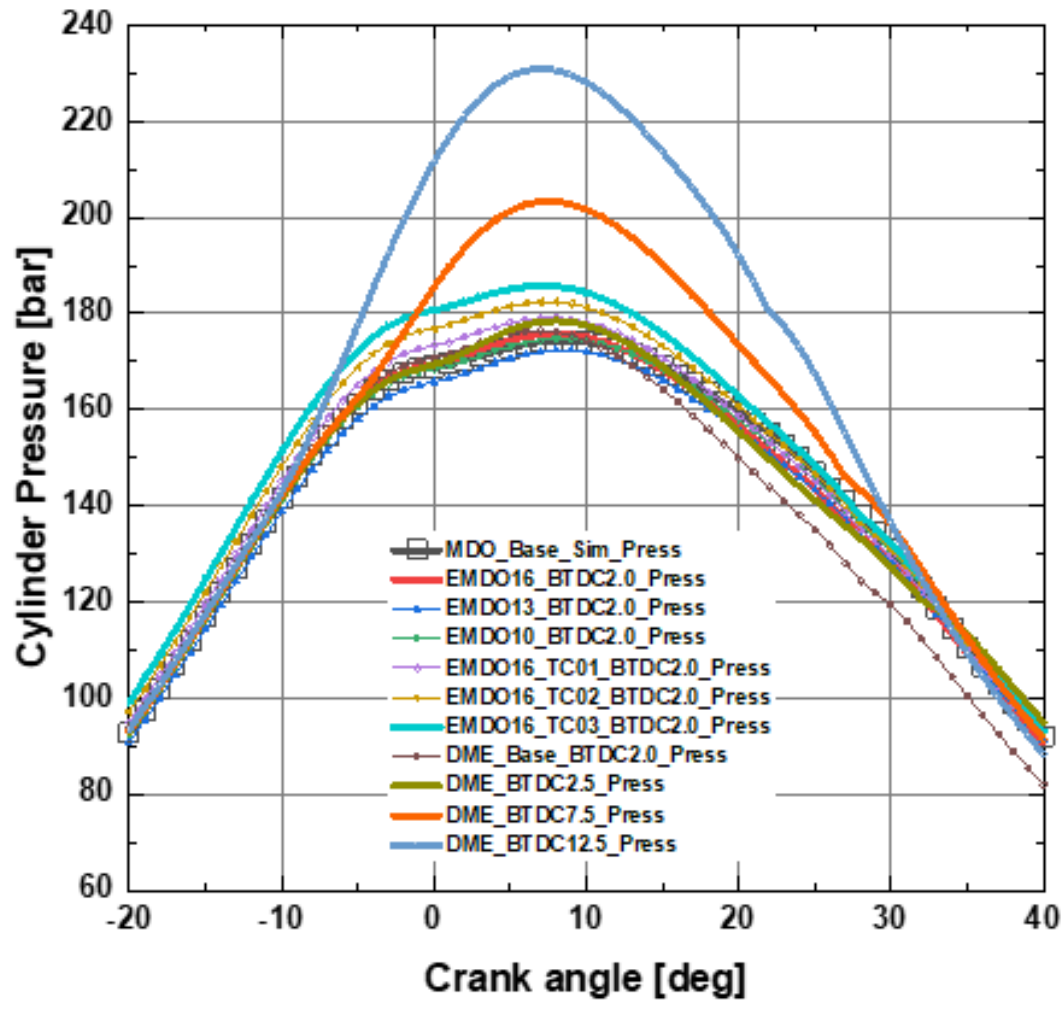

(b) Subgraph

Figure 3. Combustion pressure history of the cylinder in accordance with MDO, EMDO, and DME fuels for $100 \%$ engine loads. 


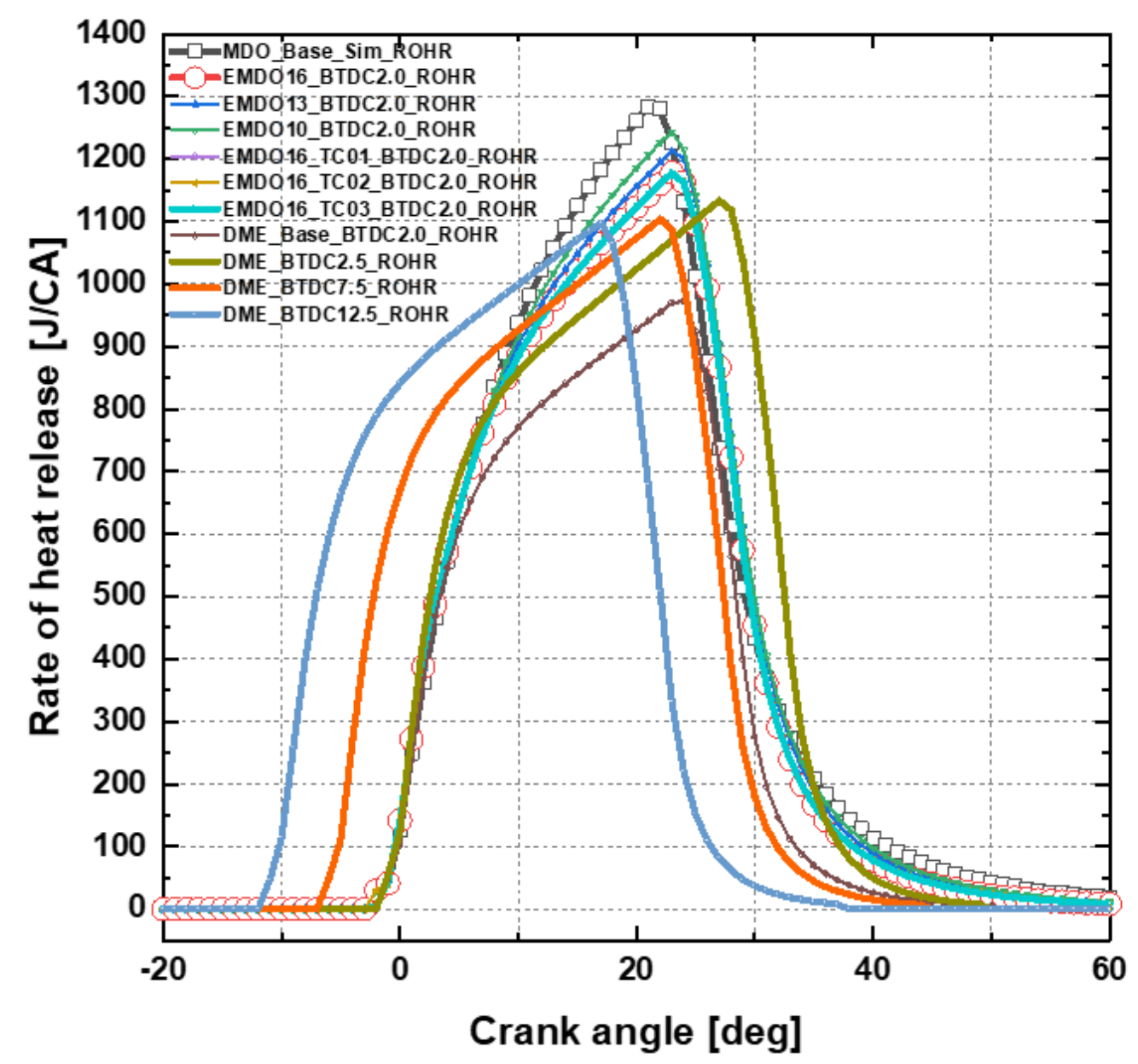

Figure 4. Rate of heat release in accordance with MDO, EMDO, and DME fuels for $100 \%$ engine loads.

\subsection{Location Characteristics on Peak Combustion Pressure in Accordance with EMDO, MDO, and DME Fuels}

Figure 5 depicts the combustion characteristics according to the location where the highest combustion pressure occurs for the various fuels, injection timing, and turbocharger pressure ratio. Using the results obtained from Figures 3 and 4, the characteristics of combustion were analyzed through the generation characteristics of the highest combustion pressure. First, when comparing the characteristic curve of the highest combustion pressure obtained using MDO fuel, most of the EMDO and DME fuels show the location of the highest combustion pressure that is perceived. This causes the tendency of the highest combustion pressure to advance through the rapid combustion of MDO fuel. As mentioned earlier, it is expected that the $\mathrm{NO}_{\mathrm{x}}$ will increase due to the increase in the combustion chamber temperature due to rapid combustion. In the case of DME fuel, the position of the highest combustion pressure is perceived in the low load region and the high load region in comparison to the MDO fuel. When the injection timing is 12.5CA BTDC, the location of the highest combustion pressure is perceived. This phenomenon is considered to occur due to the small volume elastic modulus and a longer fuel injector period because the density of fuel is less than $30 \%$ compared to the MDO through the composition of the fuel mentioned in Table 3. When the pressure ratio of the EMDO and the turbocharger is changed, the highest combustion pressure is perceived as the moisture content in the fuel increases and the pressure ratio of the turbocharger increases. These phenomena also show that the combustion chamber temperature is lowered due to atomization of the fuel and micro-explosions during the phase change due to moisture. In addition, post-combustion is rapidly exhibited due to atomization. It is believed that $\mathrm{NO}_{\mathrm{x}}$ and particulate matter can be reduced at the same time through the control of the combustion state. As mentioned earlier, the fuel's DME, which is an oxygen fuel, is a 
phenomenon in which the density and volumetric modulus of the fuel are small, since the position of the highest combustion pressure is perceived even though the injection timing is advanced.

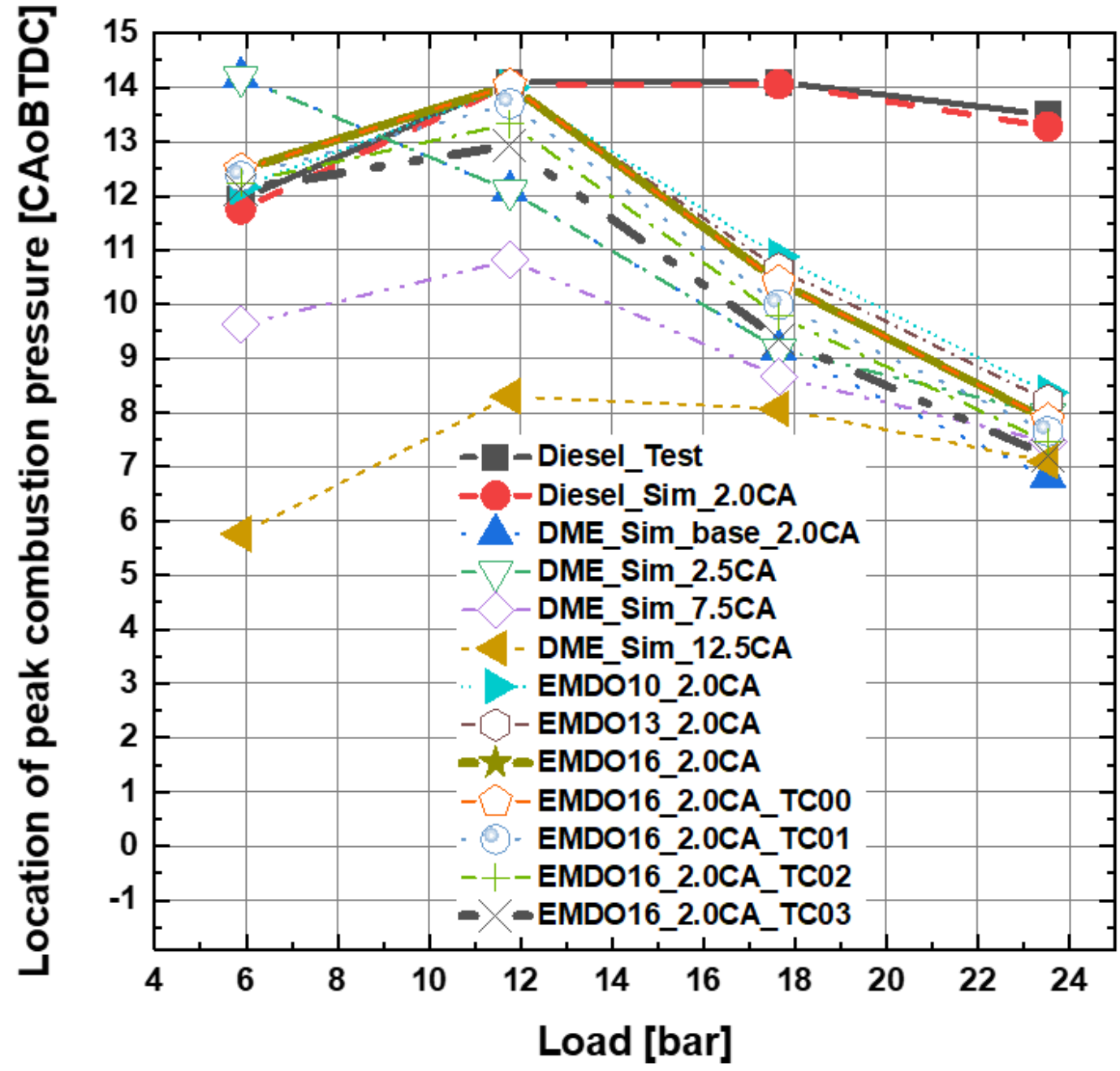

Figure 5. Location of the peak combustion pressure in a cylinder chamber in accordance with MDO, EMDO, and DME fuels.

\section{3. $\mathrm{NO}_{x}$ Reduction with EMDO, MDO, and DME Fuels}

Figure 6 shows the results of nitrogen tetrachloride for emulsified fuel according to the injection timing change, turbocharger compression ratio, and the moisture content for MDO, EMDO, and DME fuels. First, when considering the emulsifying fuel characteristics based on the moisture content, the overall $\mathrm{NO}_{\mathrm{x}}$ emissions are reduced in comparison to $\mathrm{MDO}$ fuel. The reason for this is that the moisture contained in the emulsified fuel is lowered in the combustion chamber due to the volume expansion and the latent heat effect of evaporation due to the phase change according to the temperature. It is hypothesized that the combustion was active due to the promotion of atomization due to the micro-explosion of water and fuel. In the case of emulsified fuel with a moisture content of $16 \%$, the pressure of the turbocharger was adjusted to increase the amount of intake air. Along with the micro-explosion, sufficient air was injected to promote the combustion of emulsified fuel. This is considered to be a factor that can be controlled for $\mathrm{NO}_{x}$ emission by controlling the compression ratio of the emulsified fuel and the turbocharger. In the case of DME, which contains oxygen, it emits more $\mathrm{NO}_{\mathrm{x}}$ than conventional MDO, especially at a low load. This can generate a large amount of $\mathrm{NO}_{\mathrm{x}}$ due to an increase in the pressure of the high combustion chamber. In addition, a plethora of $\mathrm{NO}_{\mathrm{x}}$ can be produced by increasing the temperature of the combustion chamber due to the injection timing. 
In order to eliminate this cause, under the same conditions as the injection timing of the MDO, $\mathrm{NO}_{\mathrm{x}}$ were reduced to a very low level compared to the combustion conditions of other emulsified fuels. It is believed that the cause of this is that fuel containing 30\% oxygen and the density of the fuel are low; hence, rapid combustion is avoided. To reduce the amount of $\mathrm{NO}_{x}$, it is considered to be a very suitable fuel for reducing $\mathrm{NO}_{\mathrm{x}}$ and the particulate matter by adjusting the compression ratio of the emulsion fuel and the turbocharger. This can also be achieved by controlling the injection period by increasing the injection timing of the DME fuel and the effective cross-sectional area of the nozzle hole.

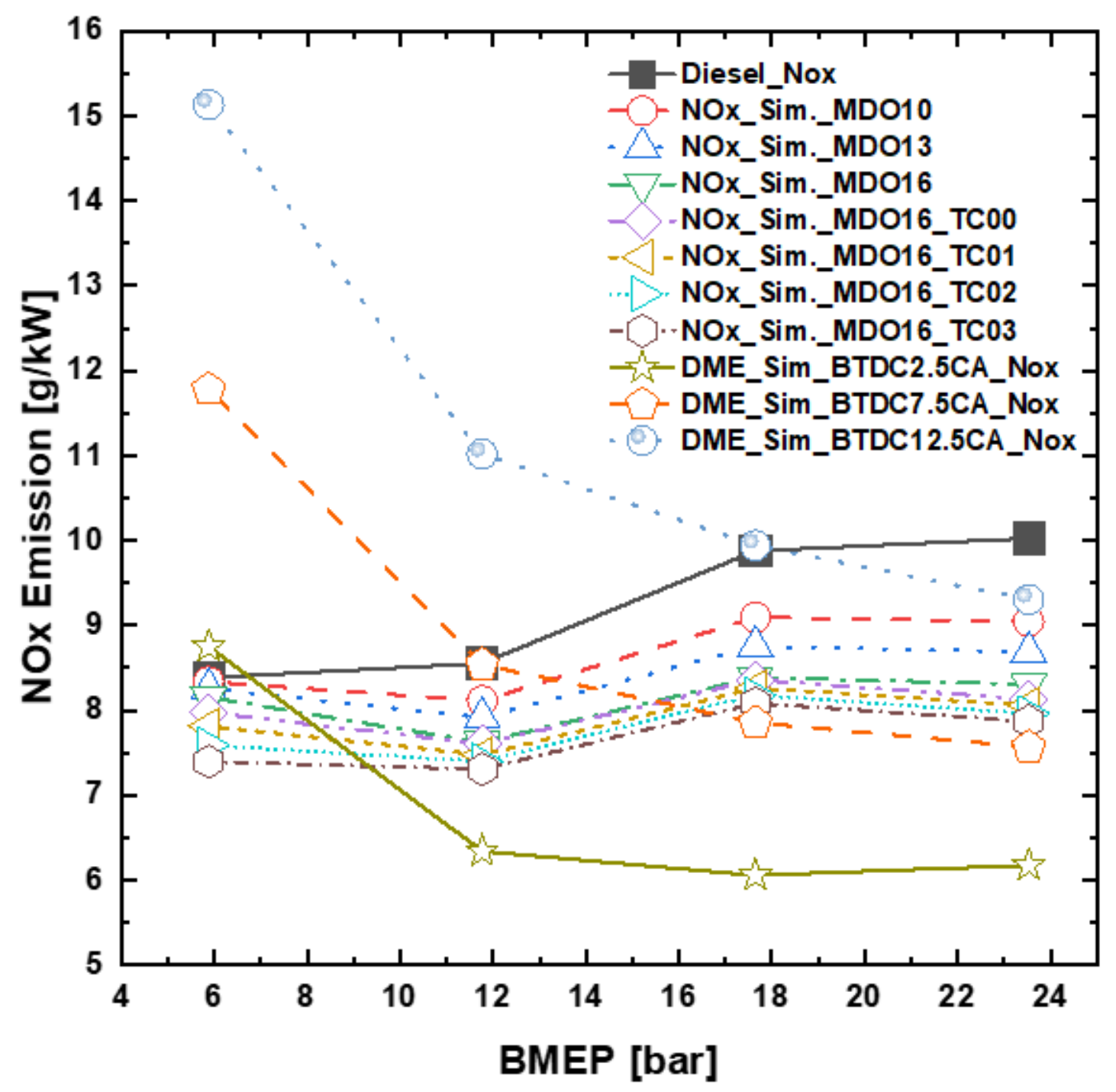

Figure 6. $\mathrm{NO}_{\mathrm{x}}$ emissions according to MDO, EMDO, and DME fuels in terms of injection timing, turbocharger compression ratio, and moisture concentration.

Figure 7 shows the results of reducing nitrogen tetrafluoride for emulsified fuel according to the injection timing change, the turbocharger compression ratio, and the moisture content for MDO, EMDO, and DME fuels. From these results, the $\mathrm{NO}_{\mathrm{x}}$ reduction characteristics of emulsified fuel and the emulsified fuel with a moisture content of $16 \%$ according to the moisture content show that the $\mathrm{NO}_{x}$ are reduced by up to $20 \%$ in comparison to the $\mathrm{MDO}$ fuel. $\mathrm{NO}_{\mathrm{x}}$ are reduced due to the increase in the moisture content and the increase in the compression ratio of the turbocharger. This is due to the atomization of the fuel that is caused by micro-explosions in the fuel, which is attributed to the volume expansion of the moisture. In addition, the volume expansion is caused by the phase change of the moisture. However, in the case of $\mathrm{DME}$ fuel, the reduction of $\mathrm{NO}_{\mathrm{x}}$ can change rapidly with the 
injection timing. When the injection timing relies on the injection timing of the existing MDO fuel, there is a reduction of up to $40 \%$. From these results, the result of adjusting the injection timing and increasing the area of the pore diameter of the fuel nozzle is displayed in Figure 8. As a result, if the nozzle hole diameter is $0.396 \mathrm{~mm}$, the nozzle diameter is suitable for $\mathrm{NO}_{\mathrm{x}}$ reduction. It is considered reasonable to determine these properties by comparing their correlation with the particulate matter.

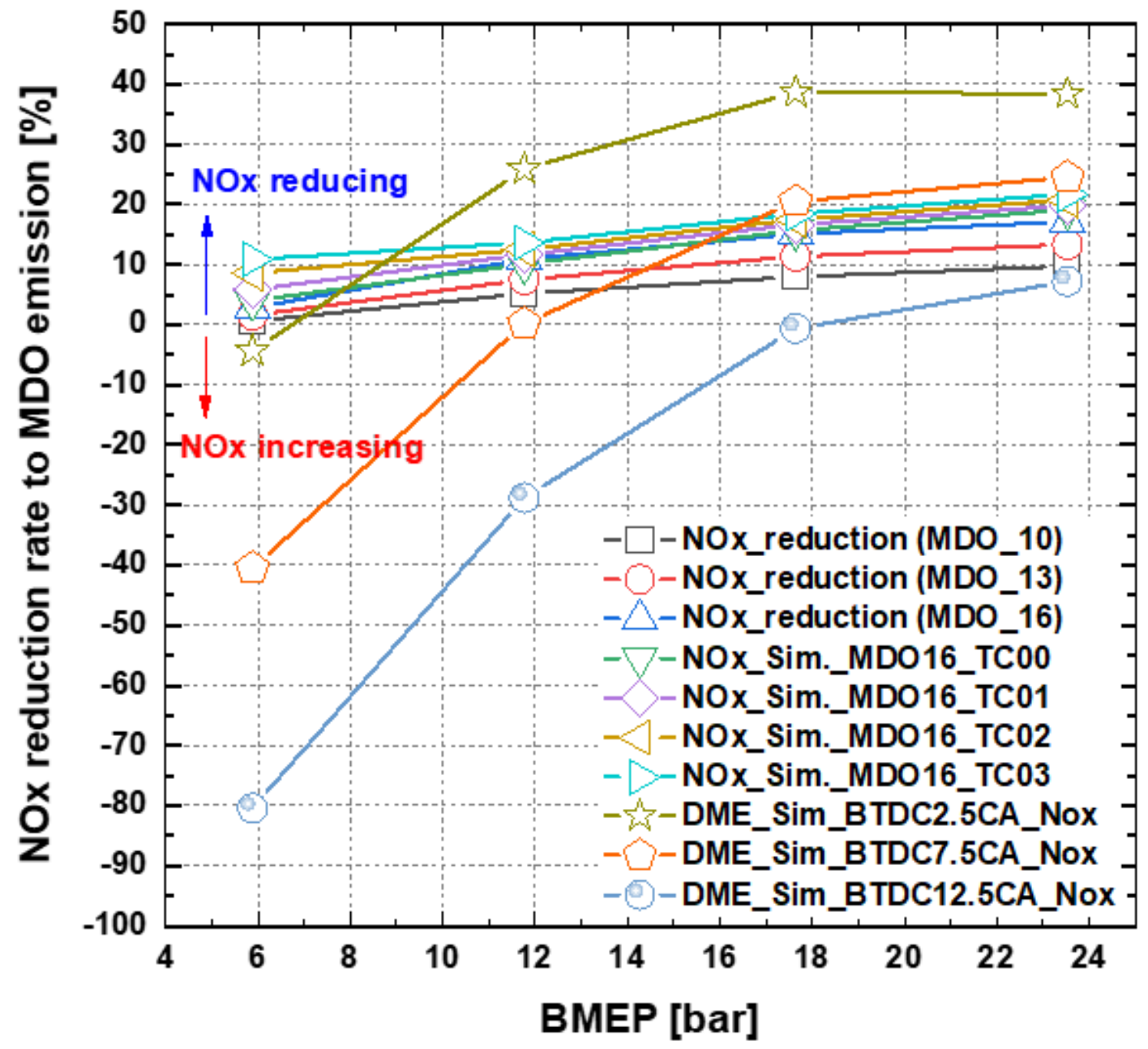

Figure 7. $\mathrm{NO}_{\mathrm{x}}$ reduction rate according to the MDO, EMDO, and DME fuels for the conditions of injection timing, turbocharger compression ratio, and moisture concentration.

Figure 9 presents the results of the emission characteristics of the emulsified fuels and the DME fuels dependent on the DME and the moisture content. Overall, the results show a decrease when using the existing MDO fuel, emulsified fuel, and DME fuel. This is because the production of particulate matter was suppressed due to the rapid combustion of post-combustion, which can be predicted from the heat generation rate curve. Figure 10 demonstrates the results of Figure 9 in terms of showing the reduction of particulate matter based on MDO fuel. When $16 \%$ of the moisture is contained and the compression ratio of the turbocharger is increased, the analysis reveals that the reduction rate of the particulate matter is reduced to $70 \%$. As a result, the increase in the excess air ratio due to the increase in the compression ratio of the turbocharger affects the reduction of $\mathrm{NO}_{\mathrm{x}}$; however, the result is somewhat slower for the reduction of particulate matter. When DME fuel is used, it reduces the particulate matter by more than $97 \%$ by comparing the results of using the existing MDO fuel and the emulsified fuel. The reason for this is believed to be that the conditions, which are suitable for combustion, are satisfied by supplying the oxygen required for post-combustion. 


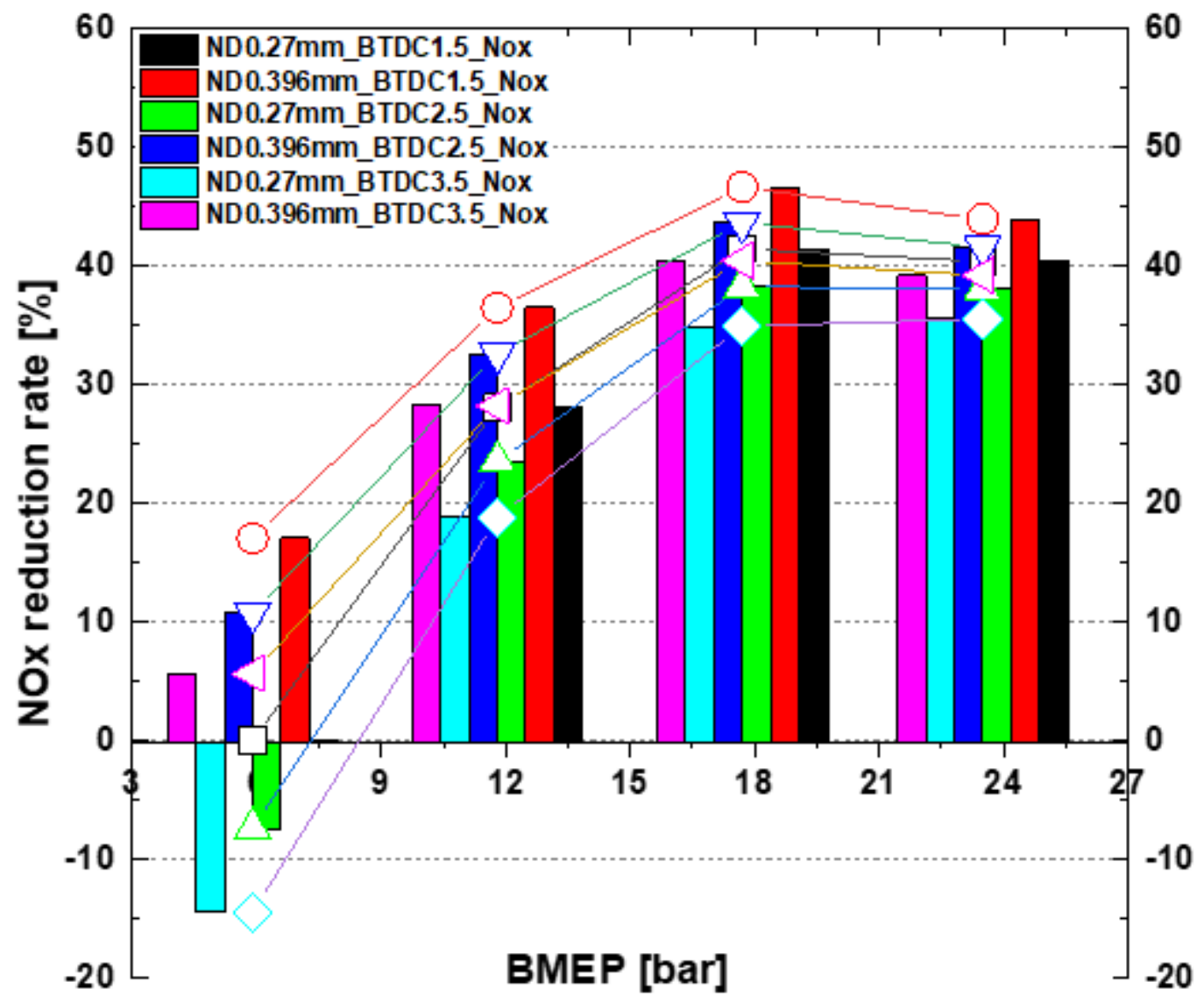

Figure 8. $\mathrm{NO}_{\mathrm{x}}$ reduction rate according to injection timing and the ratio of the nozzle hole diameter with DME fuels.

Figure 11 illustrates the results of the reduction ratio of the particulate matter according to the ratio of the pore size of the nozzle and the injection timing using DME fuel. In comparison with the results that were obtained in Figure 8, as the pore diameter increases, the tendency for the particulate matter to increase is demonstrated. In addition, the trade-off relationship of the particulate matter reduction with respect to the injection timing is also perceived. When the pore diameter is $0.27 \mathrm{~mm}$, it has no significant effect on the characteristics of the particulate matter discharge, depending on the injection timing. However, when the pore diameter is $0.396 \mathrm{~mm}$, the emission of the particulate matter increases by more than $0.27 \mathrm{~mm}$. As there is a particulate matter discharge based on the pore diameter and the injection timing, there is a trade-off relationship. 


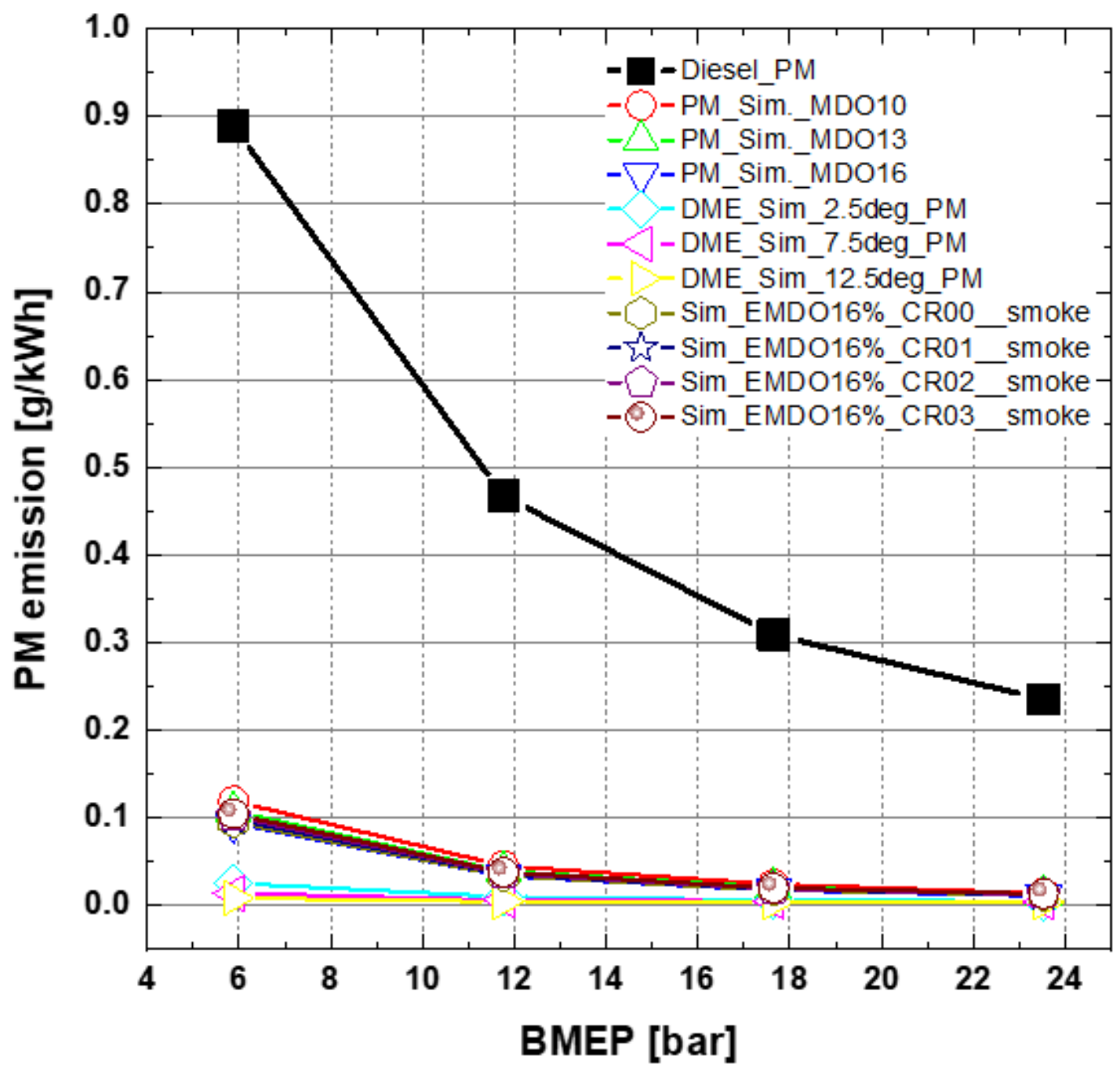

Figure 9. Particulate matter emissions according to MDO, EMDO, and DME fuels due to injection timing, turbocharger compression ratio, and moisture concentration. 


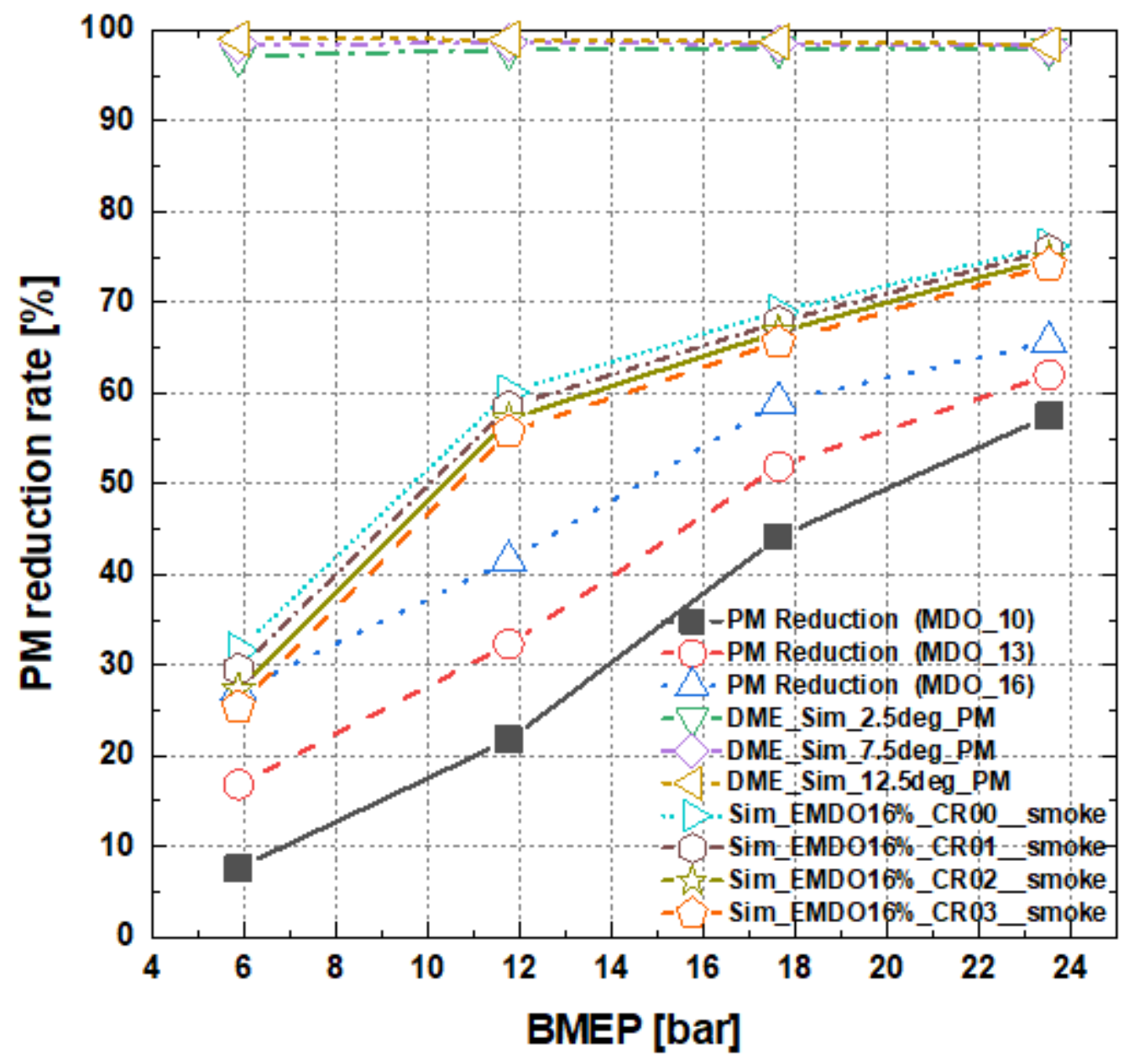

Figure 10. Particulate matter reduction rate according to MDO, EMDO, and DME fuels due to injection timing, turbocharger compression ratio, and moisture concentration. 


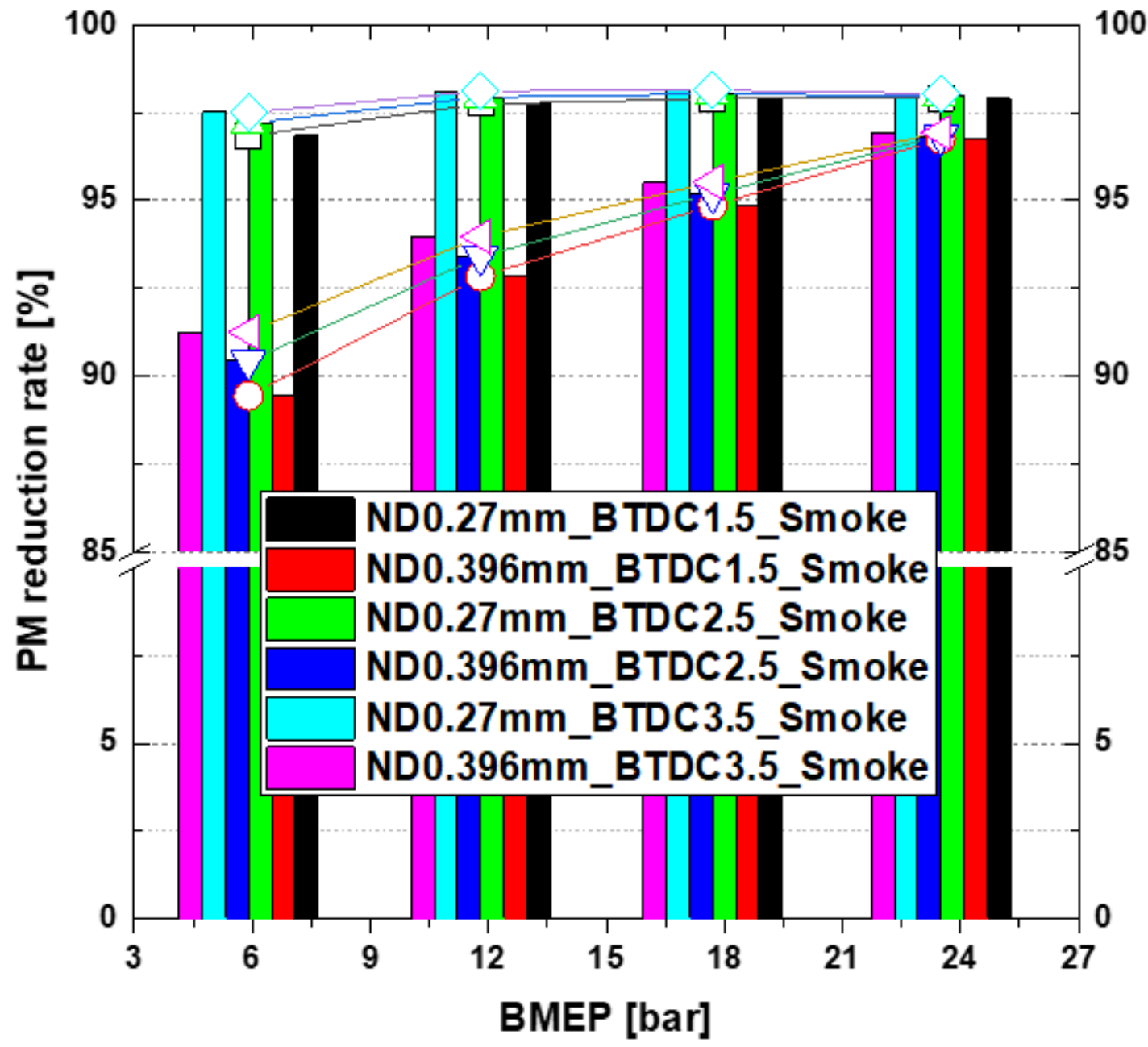

Figure 11. Particulate matter reduction rate according to injection timing and the ratio of the nozzle hole diameter with DME fuels.

\section{Conclusions}

In this study, $\mathrm{NO}_{\mathrm{x}}$ and particulate matter were simulated with $\mathrm{MDO}, \mathrm{EMDO}$, and DME within a $16 \%$ moisture concentration in accordance with the change in the turbocharger compression ratio and the DME fuels by the AVL BOOST simulation program. We first obtained the experimental data by using the MDO fuel with a $600-\mathrm{kW}$ marine auxiliary engine and then analyzed three types of fuel specifications based on the combustion and emission characteristics of marine diesel fuels. This study revealed the following findings:

(1) Based on the results of the heat generation rate in accordance with the change in the injection timing using MDO, EMDO, and DME fuels, the MDO fuel shows a rapid heat generation rate and a longer post-combustion property in comparison with EMDO and DME fuels.

(2) For the case of emulsified fuel with a moisture content of $16 \%$, the pressure of the turbocharger is adjusted to increase the amount of intake air. In addition to the micro-explosions, sufficient air is injected to promote the combustion of emulsified fuel. This is considered a factor that can be controlled for $\mathrm{NO}_{\mathrm{x}}$ emission by controlling the compression ratio of the emulsified fuel and the turbocharger.

(3) By increasing the water content of the emulsified fuel, $\mathrm{NO}_{\mathrm{x}}$ are reduced. The $\mathrm{NO}_{\mathrm{x}}$ are reduced due to the lower combustion temperature caused by the latent heat of evaporation from the phase change of water in the fuel. 
(4) By increasing the water content of the emulsified fuel, the particulate matter has a reduction efficiency of up to $60 \%$ or more. When DME fuel is used, it reduces the particulate matter by more than $97 \%$ when comparing the results of using the existing MDO fuel and the emulsified fuel. The conditions that are suitable for combustion are believed to be satisfied because of the supplied oxygen that is required for post-combustion.

Author Contributions: Conceptualization, J.P.; methodology, I.C.; investigation, J.O.; data curation, J.O.; writing — original draft preparation, C.L.; writing — review and editing, C.L. All authors have read and agreed to the published version of the manuscript.

Funding: This research received no external funding.

Conflicts of Interest: The authors declare no conflict of interest.

\section{References}

1. IMO. Annex VI of MARPOL 73/78 Regulations for the Prevention of Air Pollution from Ships and NOx Technical Code; International Maritime Organization: London, UK, 1998.

2. Marine Environment Protection Committee. Proposal to Designate an Emission Control Area for Nitrogen Oxides, Sulphur Oxides and Particulate Matter. Available online: http://www.epa.gov/nonroad/marine/ci/ mepc-59-eca-proposal-es.pdf (accessed on 7 December 2010).

3. Lim, J.K.; Cho, S.G.; Hwang, S.J.; Yoo, D.H. Effect on characteristics of exhaust emissions by using emulsified fuel in diesel engine. J. Korean Soc. Mar. Eng. 2007, 31, 44-50. (In Korean)

4. Lim, J.K.; Cho, S.G.; Hwang, S.J.; Yoo, D.H. Effects of emulsified fuel on combustion characteristics in a diesel engine. J. Korean Soc. Power Sys. Eng. 2007, 11, 51-55. (In Korean)

5. Bertola, A.; Li, R.; Boulouchos, K. Influence of water-diesel fuel emulsions and EGR on combustion and exhaust emissions of heavy-duty diesel engines equipped with common-rail injection system. SAE Tech. Pap. Ser. 2003. [CrossRef]

6. Guo, Z.; Wang, S.; Wang, X. Stability mechanism investigation of emulsion fuels from biomass pyrolysis oil and diesel. Energy 2014, 66, 250-255. [CrossRef]

7. Chauhan, B.S.; Kumar, N.; Cho, H.M.; Lim, H.C. A study on the performance and emission of a diesel engine fueled with Karanja biodiesel and its blends. Energy 2013, 56, 1-7. [CrossRef]

8. Oh, J.; Im, M.; Oh, S.; Lee, C. Comparison of $\mathrm{NO}_{\mathrm{x}}$ and smoke characteristics of water-in-oil emulsion and marine diesel oil in 400-kW marine generator engine. Energies 2019, 12, 228. [CrossRef]

9. Kim, M.; Oh, J.; Lee, C. Study on combustion and emission characteristics of marine diesel oil and water-in-oil emulsified marine diesel oil. Energies 2018, 11, 1830. [CrossRef]

10. Tsuji, Y.; Tanaka, I. Simulation technology for large marine diesel engine in dynamic response. Report Mitsui Ship. 2011, 204, 1-6. (In Japanese)

11. Ying, W.; Genbao, L.; Wei, Z.; Longbao, Z. Study on the application of DME/diesel blends in a diesel engine. Fuel Process. Technol. 2008, 89, 1272-1280. [CrossRef]

12. Lee, S.; Oh, S.; Choi, Y. Performance and emission characteristics of an SI engine operated with DME blended LPG fuel. Fuel 2009, 88, 1009-1015. [CrossRef]

13. Park, S. Optimization of combustion chamber geometry and engine conditioned for compression ignition engines fueled with dimethyl ether. Fuel 2012, 97, 61-71. [CrossRef]

14. Yeom, K.; Bae, C. Knock characteristics in liquefied petroleum gas (LPG) $=$ dimethyl ether (DME) and gasoline-DME homogeneous charge compression ignition engines. Energy Fuels 2009, 23, 1956-1964. [CrossRef]

15. Park, S. Numerical study on optimal operating conditions of homogeneous charge compression ignition engines. Energy Fuels 2009, 23, 3909-3918. [CrossRef]

16. Zhou, L.B.; Wang, H.W.; Jiang, D.M.; Huang, Z. Study of Performance and Combustion Characteristics of a DME Fuelled Light-Duty Direct Injection Diesel Engine. In Proceedings of the SAE International, Warrendale, PA, USA, 25 October 1999.

17. Fleisch, T.; McCarthy, C.; Basu, A. A new clean diesel technology: Demonstration of ULEV emissions on a Navistar diesel engine fuelled with dimethyl ether. J. Fuel. Lubr. 1995, 104, 42-53. 
18. Clausen, L.R.; Elmegaard, B.; Houbak, N. Design of Novel DME/Methanol Synthesis Plants Based on Gasification of Biomass; DCAMM Special Report, No. S123; Technical University of Denmark (DTU): Lyngby, Denmark, 2011.

19. Ying, W.; Li, H.; Jie, Z.; Longbao, Z. Study of HCCI-DI combustion and emissions in a DME engine. Fuel 2009, 88, 2255-2261. [CrossRef]

20. Xinling, L.; Zhen, H. Emission reduction potential of using gas-to-liquid and dimethyl ether fuels on a turbocharged diesel engine. Sci. Total Environ. 2009, 407, 2234-2244. [CrossRef]

21. Junjun, Z.; Xinqi, Q.; Zhen, W.; Bin, G.; Zhen, H. Experimental investigation of low-temperature combustion (LTC) in an engine fuelled with dimethyl ether (DME). Energy Fuels 2009, 23, 170-174. [CrossRef]

22. Jang, J.; Bae, C. Effects of valve events on the engine efficiency in a homogeneous charge compression ignition engine fuelled by dimethyl ether. Fuel 2009, 88, 1228-1234. [CrossRef]

23. AVL. AVL Global Emission Legislation Report 2011. Available online: https://www.avl.com/web/guest/avlfocus-2011 (accessed on 13 February 2019).

24. Loganathan, S.; Martin, M.L.J.; Nagalingam, B.; Prabhu, L. Heat release rate and performance simulation of DME fuelled diesel engine using oxygenate correction factor and load correction factor in double Wiebe function. Energy 2018, 150, 77-91. [CrossRef]

25. Benajes, J.; Novella, R.; Pastor, J.M. Computational optimization of a combustion system for a stoichiometric DME fuelled compression ignition engine. Fuel 2018, 223, 20-31. [CrossRef]

26. Lamani, V.T.; Yadav, A.K.; Narayanappa, K.G. Influence of low-temperature combustion and dimethyl ether-diesel blends on performance, combustion, and emission characteristics of common rail diesel engine: A CFD study. Environ. Sci. Pollut. Res. 2017, 24, 15500-15509. [CrossRef] [PubMed]

27. Peng, G.; Cao, E.; Tan, Q.; Wei, L. Effect of alternative fuels on the combustion characteristics and emission products from diesel engines: A review. Renew Sustain. Energy Rev. 2017, 71, 523-534.

28. Park, W.; Park, S.; Reitz, R.D.; Kurtz, E. The effect of oxygenated fuel properties on diesel spray combustion and soot formation. Combust. Flame 2017, 180, 276-283. [CrossRef]

29. Arcoumanis, C.; Bae, C.; Crookes, R.; Kinoshita, E. The potential of di-methyl ether (DME) as an alternative fuel for compression-ignition engines: A review. Fuel 2008, 87, 1014-1030. [CrossRef]

30. Cipolat, D. The Effect of Fuel Characteristics on the Fuel Injection Process in a CI Engine Fuelled on Diesel and DME. Available online: https://www.sae.org/publications/technical-papers/content/2007-24-0119/ (accessed on 15 April 2020).

31. Cipolat, D.; Bhana, N. Fuelling of a compression ignition engine on ethanol with DME as ignition promoter: Effect of injector configuration. Fuel Process. Technol. 2009, 90, 1107-1113. [CrossRef]

32. Selvan, V.A.M.; Anand, R.B.; Udayakumar, M. Combustion characteristics of diesohol using biodiesel as an additive in a direct injection compression ignition engine under various compression ratios. Energy Fuels 2009, 23, 5413-5422. [CrossRef]

33. Hao, C.; He, J.; Hua, H. Investigation on combustion and emission performance of a common rail diesel engine fueled with diesel/biodiesel/PODE blends. Appl. Therm. Eng. 2018, 31, 43-55.

34. Iannuzzi, S.E.; Barro, C.; Boulouchos, K.; Burger, J. POMDME-diesel blends: Evaluation of performance and exhaust emissions in a single cylinder heavy-duty diesel engine. Fuel 2017, 203, 57-67. [CrossRef]

35. Bhide, S.; Morris, D.; Leroux, J.; Wain, K.; Pertez, J.M.; Boehman, A.L. Characterization of the viscosity of blends of dimethyl ether with various fuels and additives. Energy Fuels 2003, 17, 1126-1132. [CrossRef]

36. Atadashi, I.M.; Aroua, M.K.; Aziz, A.A. High quality biodiesel and its diesel engine application: A review. Renew. Sustain. Energy Rev. 2010, 14, 1999-2008. [CrossRef]

37. Rashedul, H.K.; Masjuki, H.H.; Kalam, M.A.; Ashraful, A.M.; Ashrafur, S.M.; Shahir, S.A. The effect of additives on properties, performance and emission of biodiesel fuelled compression ignition engine. Energy Convers. Manag. 2014, 88, 348-364. [CrossRef]

38. Pullen, J.; Saeed, K. Factors affecting biodiesel engine performance and exhaust emissions Part II: Experimental study. Energy 2014, 2, 17-34. [CrossRef]

39. An, P.; Sun, W.; Li, G.; Tan, M.; Lai, C.; Chen, S. Characteristics of particle size distributions about emissions in a common-rail diesel engine with biodiesel blends. Proced. Environ. Sci. 2011, 11, 1371-1378.

40. Chapman, E.M.; Boehman, A.L. Pilot ignited premixed combustion of dimethyl ether in a turbodiesel engine. Fuel Process. Technol. 2009, 89, 1262-1271. [CrossRef] 
41. Curran, H.J.; Fischer, S.L.; Dryer, F.L. The reaction kinetics of dimethyl ether. II: Low-temperature oxidation in flow reactors. Int. J. Chem. Kinet. 2000, 32, 741-759.

42. Wang, Y.; Zhou, L.B.; Yang, Z.J.; Dong, H.Y. Study on combustion and emission characteristic of a vehicle engine fuelled with DME. Proc. Inst. Mech. Eng. Part D 2005, 219, 263-269.

43. Youn, I.M.; Park, S.H.; Roh, H.G.; Lee, C.S. Investigation on the fuel spray and emission reduction characteristics for dimethyl ether (DME) fuelled multi-cylinder diesel engine with common-rail injection system. Fuel Process. Technol. 2011, 92, 1280-1287. [CrossRef]

44. Kim, H.J.; Park, S.H.; Lee, K.S.; Lee, C.S. A study of spray strategies on improvement of engine performance and emissions reduction characteristics in a DME fuelled diesel engine. Energy 2011, 36, 1802-1813. [CrossRef]

45. Cocco, D.; Tola, V.; Cau, G. Performance evaluation of chemically recuperated gas turbine (CRGT) power plants fuelled by di-methyl-ether (DME). Energy 2005, 31, 1446-1458. [CrossRef]

46. Yoon, S.H.; Cha, J.P.; Lee, C.S. An investigation of the effects of spray angle and injection strategy on dimethyl ether (DME) combustion and exhaust emission characteristics in a common-rail diesel engine. Fuel Process. Technol. 2010, 91, 1364-1372. [CrossRef]

47. Park, S.H.; Kim, H.J.; Lee, C.S. Effects of dimethyl-ether (DME) spray behavior in the cylinder on the combustion and exhaust emissions characteristics of a high-speed diesel engine. Fuel Process. Technol. 2010, 91, 504-513. [CrossRef]

48. Ying, W.; Li, H.; Longbao, Z.; Wei, L. Effects of DME pilot quantity on the performance of a DME PCCI-DI engine. Energy Convers. Manag. 2010, 51, 648-654. [CrossRef]

49. Kim, M.Y.; Yoon, S.H.; Ryu, B.W.; Lee, C.S. Combustion and emission characteristics of DME as an alternative fuel for compression ignition engines with a high-pressure injection system. Fuel 2008, 87, 2779-2786. [CrossRef]

50. Kim, H.J.; Lee, K.S.; Lee, C.S. A study on the reduction of exhaust emissions through HCCI combustion by using a narrow spray angle and advanced injection timing in a DME engine. Fuel Process. Technol. 2011, 9 , 1756-1763. [CrossRef]

51. Park, S.; Choi, B.; Oh, B.S. A combined system of dimethyl ether (DME) steam reforming and lean $\mathrm{NO}_{\mathrm{x}}$ trap catalysts to improve $\mathrm{NO}_{x}$ reduction in DME engines. Int. J. Hydrogen Energy 2011, 36, 6422-6432. [CrossRef]

52. Ying, W.; Longbao, Z. Experimental study on exhaust emissions from a multi-cylinder DME engine operating with EGR and oxidation catalyst. Appl. Therm. Eng. 2008, 28, 1589-1595. [CrossRef]

53. Dimethylether. Decreasing Emissions Caused by Seagoing Vessels. Available online: www. maritimesymposium-rotterdam.nl/uploads/Route/Dimethylether.pdf (accessed on 31 March 2020).

54. Zhang, H.F.; Seo, K.; Zhao, H. Combustion and emission analysis of the direct DME injection enabled and controlled auto-ignition gasoline combustion engine operation. Fuel 2013, 107, 800-814. [CrossRef]

55. Fleisch, T.H.; Meurer, C. DME, the diesel fuel for the 21st century? In Proceedings of the Conference Program at "International Congress: Engine and Environment", Graz, Austria, 24-25 August 1995.

56. Ishida, M.; Jung, S.; Ueki, H.; Sakaguchi, D. Combustion of premixed DME and natural gas in a HCCI engine. Combust. Engines 2005, 121, 20-29.

57. Kapus, P.; Ofner, H. Development of fuel injection equipment and combustion system for DI diesels operated on di-methyl ether. J. Fuel. Lubr. 1995, 104, 54-69.

58. Djebä̈Li, N.; Paillard, C. Burning velocities of dimethyl ether and air. Combust. Flame 2001, 125, 1329-1340.

59. Sorenson, S.C.; Glensvig, M.; Abata, D. Di-metyl ether in diesel fuel injection systems. Trans. J. Fuel Lubr. 1998, 107, 438-449.

60. AVL BOOST Theory Reference. v2019 R1. Available online: https://www.avl.com/-/avl-boost-2019-r1. (accessed on 6 November 2019).

61. Choi, I.; Lee, C. Numerical study on nitrogen oxide and black carbon reduction of marine diesel engines using emulsified marine diesel oil. Sustainability 2019, 11, 6347. [CrossRef]

(C) 2020 by the authors. Licensee MDPI, Basel, Switzerland. This article is an open access article distributed under the terms and conditions of the Creative Commons Attribution (CC BY) license (http://creativecommons.org/licenses/by/4.0/). 